\title{
Crime Prevention Strategies of Bangladesh: An Analysis
}

\section{Mahmuda Akter}

Lecturer, Department of Criminology and Police Science, Mawlana Bhashani Science \& Technology University, Tangail, BANGLADESH

E-mail for correspondence: mahmudaakterhappy72@gmail.com

\begin{abstract}
The need to address crime is as old as civilization itself, and while we have always struggled with whether to punish or rehabilitate criminal activity, there has never been any question that the best alternative to 'crime' is prevention. The main objective of this study was to identify an alternative analysis of possible effective crime prevention strategies suitable for the socio-economic premises of Bangladesh. Moreover, the study also tried to find out the necessary action for implementation of crime prevention strategies. The comprehensive discussion based on secondary sources as well as documents like journal articles, authentic books. This study finds out the fields of crime prevention include a range of responses developed over many years, includes developmental, environmental, situational, social and community-based crime prevention, and interventions. Although theoretically there are very few crime prevention strategies in Bangladesh in practice, there are various strategies for crime prevention used here institutionally or un-institutionally which includes community-oriented policing and various security measures. Investing in crime prevention could reduce the drawbacks of the conventional criminal justice system. If the crime prevention strategies could ensure properly, crime and criminal victimization could prevent which will reduce the need for formal criminal justice system in Bangladesh.
\end{abstract}

Keywords: Crime Prevention, Contemporary models, Strategies, Effective Implementation

\section{INTRODUCTION}

Crime is a serious concern of contemporary societies which results widespread effect on the peaceful existence. The law enforcement agencies are struggling with controlling and preventing the challenges of crimes. In general, crime prevention refers to the range of strategies that have implemented by individuals, communities, businesses, non-government organizations and all levels of government to target various social and environmental factors that increase the risk of crime, disorder and victimization (Morgan et al. 2011). Any preventive initiative or policy may reduce, avoids or eliminates victimization by crime or violence; it includes government and non-government to decrease the fear of crime as well as the rate of crime on victims (IPC: 2008).

Crime prevention is an approach to reducing crime, which has internationally recognized as a component of a national to building feasible communities. Evidence from several countries shows that implementing and sustaining effective and efficient crime prevention programs can contribute significantly to the achievement of safe and secure societies. Well-planned interventions can prevent crime and victimization, promote community safety and make a significant contribution to the modern development of vibrant communities (Australian Institute of Criminology, 2012). Responsible crime prevention enhances the quality of life of all citizens which has longterm benefits regarding reducing the expenses associated with the formal criminal justice system, as well as other social costs that results from crime (UN, 2002).

Various models have developed to categorize the broad range of activity that falls within the definition of crime prevention. Successful strategies that prevent crime involve firstly the identification of a crime risk and secondly the development of actions designed to reduce that risk. To be effective, it requires a thorough understanding of a local crime problem, where and when it occurs, who is committing it, and who affected by it (NSW, n.d.).

The interconnected nature of many development challenges, in particular, law and order, crime and corruption remain serious problems adversely affecting 
individual safety, national security and economic growth is a reality in Bangladesh (UNDP, n.d.). Crime prevention is not just a job for the police, it must involve the entire community, agencies, groups, businesses and individuals are now collaborating to develop programs to make our municipalities safer (Crime Prevention Ottawa, 2012).

In Bangladesh, no scientific rigorous study on the topic so far had conducted. Very few popular books; newspaper, seminar and workshop were carried out in Bangladesh on crime prevention related issues. Specially, possible effective crime prevention strategies have not studied yet in large manner. If crime problem is ever to understood, controlled and reduced, it needs to have a sophisticated explanation. Once effective crime prevention strategies are this are determined, some general causal principal may proposed, rigorously test them, develop and implement better policies and practices designed to crime prevention. Recognition of effective crime prevention strategies suitable for socio-economic background of Bangladesh will be helpful to find out the limitations, barriers as well it will practical solution to overcome the problem of crime and criminal victimization. It will be helpful to find out the core issues about crime prevention. This study may look out the sectors of public demands of security to combat crime, which may show effective path towards law enforcement agencies.

\section{OBjectives}

The primary aim of this study was to analysis the existing crime prevention strategies in offering suitable crime prevention approach of Bangladesh. The following additional secondary objectives of the study were:

- To understand different successful crime prevention strategies in contemporary world.

- To recognize existing strategies and initiatives for crime prevention in Bangladesh.

- To identify the steps to planning and implementing an effective crime prevention model for Bangladesh.

\section{Methodology}

Descriptive research design had used to conduct a comprehensive study on crime prevention strategies. Data and information was collected from secondary sources such as books, journals, articles and newspapers to review the existing model and strategies of crime prevention. Data was analyzed through descriptive methods as well as comparison between various strategies and models has discussed in a qualitative manner.

\section{FINDINGS AND DISCUSSION}

\section{Crime prevention in world perspectives}

Henry Fielding, a justice of the peace in England during 1748 , had two goals, stamp out existing crime, and prevent outbreaks of crime in the future. He created the first neighborhood watch. His work with the English justice system led him to entitle the "Father of Crime Prevention" (Murrysville, n.d.).

Until 1970, the primary responsibility for crime prevention rested with the police, courts, and corrections, and the focus of their strategy was primarily to reduce the opportunity to commit a crime. The anti-crime efforts of the 1970s witnessed a move toward increased community involvement in crime prevention; Neighborhood watch is a well-known example of opportunity reduction programs of the era (John Howard, 1995). Since the 1980's the notion of crime prevention has expanded and evolved substantially, from being seen as a relatively narrow policing function, to one which involves a much broader transversal approach, and multiple state and community actors (Shaw \&Travers, 2007). Moreover, during the past few decades, studies from around the globe have successfully identified the key risk and protective factors associated with the likelihood of criminality and victimization (Department of Public Safety, 2012: 6, 15).

The workshop on crime prevention, which took place in Bangkok in April 2005 in the context of the 11th UN Congress on Crime Prevention and Criminal Justice, represented opportunity to assess progress in the application of crime prevention policy and practice around the world (Shaw \&Travers, 2007). Likewise, Poyner (1993) reviewed of 122 evaluations of crime prevention projects, the measures evaluated have grouped into six general categories: campaigns and publicity; policing and other surveillance; environmental design or improvement; social and community services; security devices; target removal or modification. From these, target removal or modification enjoyed the number of successes and social and community services the least.

The techniques and effectiveness of crime prevention continue to improve. The international trend is towards a comprehensive approach to crime prevention, and there is a growing recognition of the characteristics of effective programs that must adapt to specific circumstances. Most crime prevention and reduction approaches fall into one of three categories; Place-oriented strategies, Situationoriented strategies and People-oriented strategies (Department of Public Safety, 2012:15). Furthermore, there are two options to prevent crime: the first has tried to remove the criminal dispositions that offenders have, and the second is to remove the crime opportunities that offenders have (Gok, 2011).

Situational crime prevention increased rapidly as a viable strategy for reducing the occurrence of crimes. Based on the premise that much is contextual and opportunist-tic, situational initiatives typically alter the context to diminish the opportunities. Situational prevention helps to focus on specific situations in which violence occurs and prevent those situations gravitating or escalating to the point where violence is more likely (Indermaur, 1999). These strategies were based on the well-established notion that crimes occur most often in particular places, times, and 
circumstances. Community organization involves broader and stronger roles for citizens in preventing crime.

Clarke and Cornish (2003) developed twenty-five situational crime prevention techniques grouped into five categories: increasing the efforts, increasing the risk, reducing the rewards, reducing the provocations, and removing the excuses (Cited by Gok, 2011). Situational Crime Prevention Strategies, which have become successful are, Nuisance Abatement, Improved Street Lighting, Closed-Circuit Television (CCTV), Preventing Repeat Residential Burglary Victimization, Neighborhood Watch, etc. (Welsh \& Farrington, 2012). The most familiar situational crime prevention technique is Crime Prevention through Environmental Design (CPTED).

According to NCPC (2009), CPTED refers to the effective design, and use of the built environment to encourage a reduction in the fear of crime, in the actual number of crimes, a development in community protection, an improvement in the perception of safety, and a progress in the overall quality of life. This process involves,

- Access control through designing streets, sidewalks, building entrances, and neighborhood gateways to indicate transitions from the public environment to semi-private and private areas

- Surveillance through maximizing the visibility of people, parking areas, vehicles, and site activities

- Territorial reinforcement through sidewalks, landscaping, and porches help distinguish between public and private

- Maintenance of space

The social crime prevention model gives much-needed attention to the 'causes' of crime, especially the forces that contribute to delinquency, drug abuse, and a host of related adolescent problems. Based on that premise, crime is caused by the social ills of society, the social crime prevention model focuses on developing programs and policies to improve the health, family life, education, housing, work opportunities and neighborhood activities of potential offenders (Rosenbaum, Lurigio, and Davis, 1998).

Indermaur (1999) have cited thinking of Bottoms (1990) and Bright (1994) about criminality prevention attempts of social and developmental crime prevention techniques and crime prevention attempts of situational prevention and opined that while criminality prevention attempts to change individuals so that the propensity to offend is less, crime prevention tries to deal with situations to make offending less likely. Besides, evidence shows that social development approaches are cost-effective and are effective at reducing crime and victimization (Ontario, $\mathrm{n}$. d.).

Crime prevention through social development (CPSD) operates from the premise that crime has linked to social and economic factors; this relationship suggests prevention programs that transcend traditional opportunity reduction approaches to crime prevention (Mayor's Task Force, 1992). CPSD involves long-term, sustainable, multi-agency, integrated actions that deal with the risk factors that divert people from the path of crime, and build protective factors that may mitigate those risks (Ontario, n. d.). Moreover, CPSD strategies have addressed the social and economic causes of crime and, by the 1990s; CPSD was viewed as a vital component to any serious attempt at crime prevention (John, 1995).

According to Welsh \& Farrington (2012), Developmental crime prevention is risk-focused prevention which basic idea is very straightforward: Identify the key risk factors for offending and implement prevention methods designed to counteract them. They make reference to programs that have carried out a cost-benefit analysis. Firstly, individual and family program, where four types of programs was particularly successful: parent education (in the context of home visiting), parent management training, child skills training, and preschool intellectual enrichment programs. Secondly, Peer, School, and Community Programs, where two types of programs are particularly successful: school-based parent and teacher training, school-based anti-bullying programs, and multisystemic therapy (MST).

The most successful community-based programs are those that emphasize family interactions, probably because they focus on providing skills to the adults who are in the best position to supervise and train the child (Greenwood, 2008).

Problem-solving methodology is at the heart of crime prevention strategies used by law enforcement agencies across Australia and around the world. The technique typically involves systematic use of data and extensive progress evaluation, with an emphasis on theory, conceptuality, and implementation (Cherney, 2006). Evidence shows that police are most effective when their crime prevention efforts have combined with multisectored collaborations. Schools, governments, communities and numerous other key players all have vital roles to play Ontario (n. d.).

Sherman (2003) found that some prevention programs work, some do not, some are promising, and some have not tested adequately. Given the evidence of promising and effective programs, he finds that the effectiveness of Department of Justice funding depends heavily on whether it has directed to the urban neighborhoods where youth violence is highly concentrated. Substantial reductions in national rates of crime can only achieve by prevention in areas of concentrated poverty, where the majority of all homicides in the nation occur, and where homicide rates are 20 times the national average.

Crime prevention measures may also originate from the justice system. Targeted law enforcement strategies may focus on specific crimes or crime "hot spots." Legal sanctions may have a deterrent effect and incarceration 
may exercise an incapacitation effect by removing offenders from society. Also, interventions in custodial and community settings may design to change offender behavior and thereby prevent recidivism (Gabor, 2011).

Ontario (n. d.) indicates the pillars of a coordinated, multidisciplinary approach to crime prevention.

- Prevention through Social Development by targeting risk factors associated with crime and victimization

- Prevention through Situational Measures by reducing the opportunity to commit crime

- Prevention through Education and Awareness of all Ontarians, including building knowledge about local communities and their needs
- Prevention through Community Policing by enhancing policing efforts and supporting the police in their crime prevention activities

Any crime intervention project must include crime diagnosing crime problem using opportunity theories; deciding the intervention to apply; consider displacement and diffusion of benefit probability (Gok, 2011). Additionally, Cost-effectiveness and cost-benefit studies make it possible to compare the efficiency of programs that produce similar results, allowing policymakers to achieve the possible crime-prevention effect for a given level of funding (Greenwood, 2008).

Table 1: Comparative Table on Successful Crime Prevention Model, Strategies and Projects

\begin{tabular}{|c|c|c|c|c|c|}
\hline $\begin{array}{c}\text { Name of the } \\
\text { Model/Strategy/Project }\end{array}$ & Basic Concepts & Nature & Outcome & Strength & Weakness \\
\hline $\begin{array}{c}\text { Chicago Alternative } \\
\text { Police Strategy } \\
\text { (USA) } \\
\end{array}$ & $\begin{array}{l}\text { Bringing police, citizen } \\
\text { and community agencies } \\
\text { together to prevent crime } \\
\text { rather than react to it. }\end{array}$ & $\begin{array}{l}\text { Problem-oriented } \\
\text { policing at the } \\
\text { neighborhood level }\end{array}$ & $\begin{array}{l}\text { Reducing } 50 \\
\text { percent in gangs, } \\
\text { drugs and other } \\
\text { serious crimes }\end{array}$ & $\begin{array}{c}\text { Improving } \\
\text { relations } \\
\text { between police } \\
\text { and community }\end{array}$ & $\begin{array}{c}\text { Rates of } \\
\text { murder never } \\
\text { came down }\end{array}$ \\
\hline $\begin{array}{c}\text { The Boston Strategy } \\
\text { (USA) }\end{array}$ & $\begin{array}{l}\text { Operation Ceasefire } \\
\text { and combined crime } \\
\text { prevention programs }\end{array}$ & $\begin{array}{l}\text { Problem-oriented } \\
\text { policing and Crime } \\
\text { Prevention through } \\
\text { Social Development }\end{array}$ & $\begin{array}{l}66 \text { percent drop in } \\
\text { youth homicide }\end{array}$ & $\begin{array}{l}\text { Combine } \\
\text { strategies }\end{array}$ & $\begin{array}{l}\text { No scientific } \\
\text { evaluation }\end{array}$ \\
\hline $\begin{array}{c}\text { Communities that Care } \\
\text { (USA, UK, Netherlands, } \\
\text { Australia) }\end{array}$ & $\begin{array}{c}\text { Designed to tackle the } \\
\text { risk factors that given } \\
\text { youth to persistent } \\
\text { delinquency } \\
\end{array}$ & $\begin{array}{c}\text { Community } \\
\text { oriented strategy }\end{array}$ & $\begin{array}{l}\text { Stopping drug } \\
\text { abuse }\end{array}$ & $\begin{array}{l}\text { Sound research } \\
\text { about difficulties }\end{array}$ & $\begin{array}{l}\text { Tough to } \\
\text { identify risk } \\
\text { factors }\end{array}$ \\
\hline $\begin{array}{l}\text { Secure by Design } \\
\text { (Netherlands) }\end{array}$ & $\begin{array}{c}\text { A manual on secure } \\
\text { housing by design to } \\
\text { help housing project } \\
\text { developers }\end{array}$ & $\begin{array}{l}\text { Crime Prevention } \\
\text { Through } \\
\text { Environmental } \\
\text { Design } \\
\end{array}$ & $\begin{array}{l}\text { Reduce } 50 \text { percent } \\
\text { burglary than } \\
\text { those did not } \\
\text { secured by design }\end{array}$ & $\begin{array}{l}\text { Designing the } \\
\text { residential area }\end{array}$ & $\begin{array}{l}\text { Not applicable } \\
\text { for those } \\
\text { already build } \\
\text { the house } \\
\end{array}$ \\
\hline $\begin{array}{l}\text { Community Crime } \\
\text { Prevention Project } \\
\text { (USA) }\end{array}$ & $\begin{array}{l}\text { Community crime } \\
\text { prevention through } \\
\text { neighborhood watch }\end{array}$ & $\begin{array}{c}\text { Community } \\
\text { oriented strategy }\end{array}$ & $\begin{array}{l}\text { Reduction of } 50 \\
\text { percent } \\
\text { residential } \\
\text { burglary } \\
\end{array}$ & $\begin{array}{l}\text { Diagnosing risk } \\
\text { factors }\end{array}$ & $\begin{array}{l}\text { Excessive cost } \\
\text { of money }\end{array}$ \\
\hline $\begin{array}{l}\text { Mother Against } \\
\text { Drunken Driving } \\
\text { (USA) }\end{array}$ & $\begin{array}{l}\text { Stop drunken driving, } \\
\text { support the victims and } \\
\text { prevent underage } \\
\text { drinking }\end{array}$ & $\begin{array}{l}\text { Evidence-Based } \\
\text { Crime Prevention }\end{array}$ & $\begin{array}{l}\text { Reduce the loss of } \\
\text { life and the } \\
\text { injuries from } \\
\text { drinking and } \\
\text { driving }\end{array}$ & $\begin{array}{c}\text { Raising } \\
\text { minimum age of } \\
\text { buying alcohol }\end{array}$ & $\begin{array}{l}\text { Tough and } \\
\text { difficult } \\
\text { procedure }\end{array}$ \\
\hline $\begin{array}{c}\text { Towards no Drug use } \\
\& \\
\text { Midwestern Project } \\
\text { (Colorado, USA) }\end{array}$ & $\begin{array}{l}\text { Avoid drug abuse from } \\
\text { primary to secondary } \\
\text { school by training } \\
\text { student in life skill and } \\
\text { provide information to } \\
\text { avoid drug } \\
\end{array}$ & $\begin{array}{c}\text { Community } \\
\text { oriented strategy } \\
\text { and Crime } \\
\text { Prevention through } \\
\text { Social Development }\end{array}$ & $\begin{array}{l}\text { Avoid } 20 \text { to } 40 \\
\text { percent reduction } \\
\text { in drug abuse }\end{array}$ & $\begin{array}{l}\text { Works with the } \\
\text { parent, school, } \\
\text { media, } \\
\text { community } \\
\text { organization and } \\
\text { health policy } \\
\end{array}$ & $\begin{array}{c}\text { Time } \\
\text { consuming }\end{array}$ \\
\hline $\begin{array}{l}\text { Youth Inclusion } \\
\text { Program } \\
\text { (England \& Wales) }\end{array}$ & $\begin{array}{l}\text { Youth were provided ten } \\
\text { hours a week of } \\
\text { activities, including } \\
\text { sports, training in } \\
\text { information technology, } \\
\text { etc. } \\
\end{array}$ & $\begin{array}{c}\text { Crime Prevention } \\
\text { through Social } \\
\text { Development }\end{array}$ & $\begin{array}{l}\text { Decrease } 65 \\
\text { percent of youth } \\
\text { arrest, } 16 \text { percent } \\
\text { reduce in overall } \\
\text { crime. }\end{array}$ & $\begin{array}{l}\text { Utilizing leisure } \\
\text { of youth }\end{array}$ & $\begin{array}{l}\text { Tough to apply } \\
\text { for a large } \\
\text { number }\end{array}$ \\
\hline $\begin{array}{l}\text { Preventing Violence } \\
\text { Against Women \& } \\
\text { Children (PVAC) } \\
\text { strategy } \\
\text { (Canada) }\end{array}$ & $\begin{array}{c}\text { Addresses the } \\
\text { determinants of violence } \\
\text { against women and } \\
\text { builds the capacity of } \\
\text { communities to take } \\
\text { action }\end{array}$ & $\begin{array}{l}\text { Community and } \\
\text { Government } \\
\text { Partnerships }\end{array}$ & $\begin{array}{c}\text { Reducing } \\
\text { Violence against } \\
\text { Women and their } \\
\text { Children }\end{array}$ & $\begin{array}{l}\text { Promoting equal } \\
\text { and respectful } \\
\text { relationships } \\
\text { between men } \\
\text { and women at } \\
\text { all levels }\end{array}$ & $\begin{array}{l}\text { High budget } \\
\text { and time } \\
\text { consuming(app } \\
\text { roximately } \\
\text { three years) }\end{array}$ \\
\hline
\end{tabular}




\begin{tabular}{|c|c|c|c|c|c|}
\hline $\begin{array}{c}\text { Functional Family } \\
\text { Therapy }\end{array}$ & $\begin{array}{l}\text { Helping youths and their } \\
\text { family to improve } \\
\text { situation }\end{array}$ & $\begin{array}{c}\text { Crime Prevention } \\
\text { through Social } \\
\text { Development }\end{array}$ & $\begin{array}{l}25 \text { to } 60 \text { percent } \\
\text { reduction }\end{array}$ & $\begin{array}{c}\text { Cost-effective } \\
\text { program }\end{array}$ & $\begin{array}{l}\text { Working with } \\
\text { risky youths } \\
\text { only }\end{array}$ \\
\hline $\begin{array}{c}\text { Chicago child-Parent } \\
\text { Centre Program } \\
\text { (USA) }\end{array}$ & $\begin{array}{l}\text { Help inconvenience } \\
\text { children to prepare for } \\
\text { elementary school }\end{array}$ & $\begin{array}{l}\text { Crime Prevention } \\
\text { through Social } \\
\text { Development }\end{array}$ & $\begin{array}{l}32 \text { percent reduce } \\
\text { to arrest rate }\end{array}$ & $\begin{array}{l}\text { Helps the family } \\
\text { of high poverty } \\
\text { neighborhood }\end{array}$ & $\begin{array}{l}\text { Tough to work } \\
\text { with a large } \\
\text { number of } \\
\text { inconvenience } \\
\text { children }\end{array}$ \\
\hline $\begin{array}{l}\text { Nurse-Family } \\
\text { Partnership } \\
\text { (Colorado, } \\
\text { USA) }\end{array}$ & $\begin{array}{c}\text { Home Visitation and } \\
\text { Parent Training by } \\
\text { nurses }\end{array}$ & $\begin{array}{c}\text { Crime Prevention } \\
\text { through Social } \\
\text { Development }\end{array}$ & $\begin{array}{l}\text { Child abuse and } \\
\text { neglect was } \\
\text { considerably } \\
\text { reduced }\end{array}$ & $\begin{array}{l}\text { Effective for } \\
\text { early cognitive } \\
\text { development }\end{array}$ & $\begin{array}{c}\text { Not } \\
\text { representative } \\
\text { of inner cities } \\
\text { or extremely } \\
\text { isolated rural } \\
\text { communities }\end{array}$ \\
\hline $\begin{array}{l}\text { Life-Skill Training } \\
\text { (LST) } \\
\text { (Boulder, USA) }\end{array}$ & $\begin{array}{c}\text { Alcohol Prevention and } \\
\text { Treatment, Cognitive- } \\
\text { Behavioral Training, } \\
\text { Drug } \\
\text { Prevention/Treatment, } \\
\text { School - Individual } \\
\text { Strategies, Skills } \\
\text { Training }\end{array}$ & $\begin{array}{c}\text { Crime Prevention } \\
\text { through Social } \\
\text { Development }\end{array}$ & $\begin{array}{c}\text { Reductions of } 32 \% \\
\text { in delinquency } \\
\text { and criminal } \\
\text { behavior }\end{array}$ & $\begin{array}{l}\text { - Multiple } \\
\text { outcomes and } \\
\text { follow-up } \\
\text { periods }\end{array}$ & $\begin{array}{l}\text { Working with } \\
\text { schools only }\end{array}$ \\
\hline
\end{tabular}

Note: The above table has constructed from the writings of Waller (2006), WHGNE (n.d.) \& Blueprints (n.d.)

\section{Existing crime prevention strategies of Bangladesh}

Theoretically, there are very few crime prevention strategies in Bangladesh. But in practice, there are various strategies for crime prevention used here institutionally or un-institutionally. Most common crime prevention strategy in Bangladesh is community-based prevention program, which are continuing here in the title of community policing. Here, initial efforts, led by the Bangladesh Police, started as early as 1992 in Mymensingh and Natore Districts, and then spread to other parts of Bangladesh. This work has later strengthened through a 2008 national strategy for community policing (TAF, 2013).

The Police Reform Programme (PRP) is a long-term and comprehensive capacity building initiative to improve human security in Bangladesh (UNDP, n.d.). PRP has initiated to support the Bangladesh Police to implement the National Community Policing Strategy, which outlines the standards and guidelines for the operation of over 20,000 Community Policing Forums, Thana Open Days, and the training of key personnel. The Forums have designed to improve the security of the local community by solving local problems in a participatory manner. It has expected that the forums will help to create a more accessible, accountable and effective police service by conducting outreach programmes like school visits and awareness campaigns on local issues (PRP, n.d.)

The PRP community policing initiative was focused on establishing a small number of "Model Thanas", which are police stations equipped with modern facilities at which model policing is practiced, and "Community Policing Forums" (CPF), a much effort to set up 20,000 mechanisms for consultation between communities and police to improve security and solve local problems (Crisis Group Asia, 2009).
One of the key components identified in police reform program is Crime Prevention (PRP, n.d.). Consequently, the Crime Prevention Center (CPC) Was created As a focal point at Police Headquarters in Dhaka for organizing, tracking and supervising all community policing efforts nationwide (TAF, 2013). It acts as central research, policy and strategic formulation unit for Bangladesh Police, to support local Police and civil society efforts in prevention of crime and implementation of community policing (PRP, 2009).

The main objective of this Outcome is to establish a sustainable structure through which community policing will function. These are from the Crime Prevention Cell at Headquarters to District level and down to the Thana and the individual Forum. To achieve this PRP will target 8,400 Forums and will build police capacity to monitor operational implementation by the National Community Policing Strategy. Community policing initiatives will also initiate in the Chittagong Hill Tracts, which models better service delivery for the indigenous population who have traditionally struggled to access justice (PRP, n.d.).

The Bangladesh Police Women's Network has established as a national and regional milestone towards the implementation of the Women in Policing Strategy, and the broader goal of police reform (UNDP, n.d.). Now in Bangladesh, MOHA and Bangladesh Police are taking the lead role in establishing a crime prevention and community safety program through its efforts to implement the Community Policing Strategy (CPS) throughout the country (PRP, 2009). But, the survey detected a decrease in external interference in police affairs at Model Thana's from 72 percent in 2006 to 55 percent in 2008 while "no appreciable change" was noticed in nonmodel stations over the same period (Crisis group Asia, 2009). 
The National Crime Prevention Strategy has the following objectives (PRP, 2009):

- The establishment of a comprehensive policy framework that will enable the government to address crime in a coordinated and focused manner, which draws on the resources of all government agencies, as well as civil society.

- The promotion of a shared understanding and vision of how we, as a nation, are going to tackle crime. This vision should also inform and stimulate initiatives at divisional and local level.

- The maximization of civil society's participation in mobilizing, and sustaining crime prevention initiatives.

- The development of a set of national programs, which serve to kick-start and focus the efforts of various government departments in delivering quality service aimed at solving the problems leading to high crime levels.

- Creation of a dedicated and integrated crime prevention capacity, which can conduct ongoing research and evaluation of departmental and public campaigns as well as facilitating crime prevention program at divisional and local level.

Besides Bangladesh Police, its branches and organization under it, Bangladesh Ansar is a disciplined force for the preservation of internal security and law enforcement in Bangladesh. Approximately 40,000 Sadharon Ansars are embodied, and deployed with various organizations for security and protection duty. They are guarding different important KPIs and organizations like airports, seaports, land ports, industries, public transports, residential zones, power stations, banks, agricultural farms, shopping malls, government offices, RMG industries and deployed with police for internal security duty, traffic control and maintaining law and order. Moreover, 600 Sadharon Ansars and 7,887 hill-VDP are embodied as Hill Ansar and deployed with Army in CHTs for security and protection duty (Ansar, n.d.).

Steps to planning and implementing an effective crime prevention model for Bangladesh:

Crime analysis: Successful crime prevention strategies require careful analysis; knowing as much a possible about the crime and its social context can help determine the best prevention strategies. Concentrate efforts on addressing crime problems that present the threat to the safety, security, and cohesiveness of communities should imply.

Social Development: Improve literacy rates, increase employment opportunities, equal opportunities, equity, provide aggression management and counseling, improvement of the moral values and respects could ensure reduction of violence.

Educational programs: Programs those teach parenting skills, educational programs for at-risk youth, and employment programs for adults. These programs address the risk or protective factors that are predictive of individual involvement in delinquency and criminality.
Community involvement: Neighborhood Watch and Citizens on Patrol where community members actively become part of the crime prevention effort should ensure. Community Engagement in developing pro-active initiatives is also necessary.

Effective policing: The police can work proactively to prevent crime. Visible police patrols in high crime areas, mandatory arrests of some types of domestic violence offenders, and curfew checks for young auto theft offenders are methods that have demonstrated some success in reducing crime.

Designing Environment: Increasing the surveillance of potential targets or reducing their attractiveness can help reduce crime. Targeted law enforcement strategies may focus on specific crimes or in crime "hot spots." Legal sanctions may have a deterrent effect and incarceration may exercise an incapacitation effect by removing offenders from society.

Administrative Programs: Changes in legislation and businesses practices may help to prevent crime. Zoning bylaws can keep undesirable businesses that may create problems away from residential neighborhoods.

Continuing progression for sustainability: Continuing to monitor local crime problems, identify local priorities and develop strategies to reduce their impact on the community, addressing new and emerging crime problems for improving the evidence base for crime prevention.

As a first step, it needs to raise awareness, generate a dialogue on crime prevention in Bangladesh, and highlight the opportunities to move forward. Then set the stages for the development of further crime prevention work that will build and enhance crime prevention partnerships; encourage the development of coordinated, multi-sector responses; and promote community leadership and participation in crime prevention.

\section{CONCLUSION}

Crime prevention today is an essential instrument for bringing down the crime rate, including crimes that have reported to police and those that remain undisclosed. It makes neighborhoods safe and at the same time ensures that people's rights and freedoms have respected. Crime prevention allows communities to work to reduce the motivation and risk factors associated with crime thereby safeguarding potential victims. Developmental or early prevention involves the organized provision of resources to individuals, families, schools or communities to forestall the later development of crime or other problems. The government should maintain some strategies for prevention of crime. It should target hot spots, stop the spiral of decay by cleaning up rubbish, graffiti and so on, reduce residential mobility and scatter public housing in a broad range of neighborhoods. It is essential to promoting community power through community organizations, encouraging community leadership and responses to the 
community problem. Empowering residents through vocational training and employment opportunities, getting young people back into school and support to stay in school, helping young people make the transition to a working life will help to prevent youth criminality. Improvement of resident's knowledge of available public services and community support services and Work with groups of residents so that they can develop new life and community management skills. Moreover, Encourage a partnership approach between public, private, volunteer, charitable and community organizations to assist the community.

\section{REFERENCES}

Ansar (n.d.). About Ansar. Retrieved on July 13, 2017 from http:/ / www.ansarvdp.gov.bd/

Australian Institute of Criminology (2012). National Crime Prevention Framework-Overview. Retrieved on June 17, 2014 from http:/ / www.aic.gov.au/

Bottoms, A. (1990). Crime prevention facing the 1990s. Policing and Society, 1, retrieved on July 9, 2017 from https:/ / pdfs.semanticscholar.org/d41a/e1624a02d167b73cc 6901cd3a4ae1d579911.pdf

Bright, J. (1994). Preventing youth crime: towards a strategy. Paper delivered at Australian Institute of Criminology Conference, New South Wales. Retrieved on May 8, 2017 from https:/ / pdfs.semanticscholar.org/d41a/e1624a02d167b73cc 6901cd3a4ae1d579911.pdf

Cherney, Adrian (2006). Problem solving for crime prevention. Trends \& Issues in crime and criminal justice, Australian Institute of Criminology.

Clarke, Ronald V. and Cornish, (2003). Opportunities, Precipitators, and Criminal decisions: A Reply Worley's Critique o Situational Crime Prevention, Retrieved on June 23, 2017 from http:/ /www.popcenter.org/Responses/crime_prevention/ PDFs/Cornish\%26Clarke.pdf

Crime prevention in Ontario (2009), A Framework of Action, Retrieved on July 9, 2017 from https://www.mcscs.jus.gov.on.ca/sites/default/files/cont ent/mcscs/docs/ec157730.pdf

Crime Prevention Ottawa (2012). Why Community-Based Crime Prevention Works. Retrieved on June 18, 2014 from Ca http:/ / centerforplainlanguage.org/wpcontent/uploads/2012/05/Crime-PreventionOttawa_AFTER.pdf

Crisis Group Asia (2009). Bangladesh: getting police reform on track. Retrieved on June 27, 2017 from http:/ / www.refworld.org/pdfid/4b22758b2.pdf

Department of Public Safety (2012). Moving from Theory to Outcomes: New Brunswick's Crime Prevention and Reduction Strategy. Retrieved on June 11, 2017 from http://www2.gnb.ca/content/dam/gnb/Departments/ps$\mathrm{sp} / \mathrm{pdf} /$ Publications

Gabor, Thomas (2011). Evidence-based crime prevention programs: A literature review. Palm Beach County Board of County Commissioners and Criminal Justice Commission.

Gok, Ozkan (2011). The role of opportunity in crime prevention and possible threats of crime control benefits. Turkish Journal of Police Studies Vol: 13 (1).
Greenwood, Peter (2008). Prevention and Intervention Programs for Juvenile Offenders. The Future of children, VOL. 18 / NO. 2 / FALL 2008.

Indermaur, David (1999). Situational Prevention of Violent Crime: Theory and Practice in Australia. Crime Research Centre, University of Western Australia.

Institute for the Prevention of Crime (IPC) (2008). What is crime prevention? Canada: University of Ottawa. Retrieved on June 23, 2017 from http:/ / www.sciencessociales.uottawa.ca/ipc/eng/

John, Howard (1995). Crime Prevention through Social Development: A literature review. The John Howard Society of Alberta.

Mayor's Task Force on Safer Cities (1992). Mayor's task force on safer cities final report: Toward a safer Edmonton for all. Edmonton. AB: City of Edmonton.

Morgan, Anthony, Boxall, Hayley, Lindeman, Kym, Anderson, Jessica (2011). Effective crime prevention interventions for implementation by local government. AIC Reports: Research and Public Policy Series, Australian Institute of Criminology.

Murrysville (n.d.). A Short History of Crime Prevention. Retrieved on June 20, 2017 from http:/ / www.murrysville.com/

National Crime Prevention Council (NCPC) (2009). Best practice for Using Crime Prevention through Environmental Design in Weed and Seed Sites. USA: NCPC.

NSW (n.d.). Guidelines for developing a crime prevention strategy. Retrieved on June 18, 2017 from http:/ /www.crimeprevention.nsw.gov.au

Poyner, Barry (1993). What works in crime prevention: an overview of evaluations? Crime Prevention Studies (Vol. 1), United Kingdom.

PRP (2009). National Crime prevention and community safety strategy of Bangladesh. Bangladesh police. Retrieved on June 17, 2014 from http:/ / www.prp.org.bd/downloads/

PRP (n.d.). Crime Prevention and Community Policing. Retrieved on June 27, 2017 from http:/ / www.prp.org.bd/

Rosenbaum, D. P., Lurigio, A.J. and Davis, R. C. (1998). The Prevention of Crime: Social and Situational Strategies. West/Wadsworth, Belmont.

Shaw, Margaret \& Travers, Kethryn (2007). Strategies and Best Practices in Crime Prevention in particular in relation to Urban Areas and Youth at Risk. Montreal: International Centre for the Prevention of Crime.

Sherman, Lawrence W. (2003). Preventing crime: an overview. In Preventing crime: what works, what doesn't, what's promising? Department of Criminology and Criminal Justice University of Maryland

The Asia Foundation (TAF) (2013). Community Policing Assessment: Progress and Opportunities in Bangladesh. Asia foundation and Bangladesh police.

UN (2002). ECOSOC Resolution 2002/13. Retrieved on June 17, 2017 from http://www.un.org/en/ecosoc/docs/2002/resolution $\% 20$ 2002-13.pdf

UNDP (n.d.). Bangladesh: Police Reform Programme. Retrieved on June 25, 2017 from http://web.undp.org/comtoolkit/success-stories/ASIABangladesh-demgov2.shtml 
Waller, Irvin (2006). Less Law, More Order: The Truth about Reducing Crime. Ontario: Manor house Publishing Inn.
Welsh, Brandon C. \& Farrington, David P. (2012). The Future of Crime Prevention: Developmental and Situational Strategies. Maryland: National Institute of Justice.

$--0--$

How to Cite: Akter, M. (2018). Crime Prevention Strategies of Bangladesh: An Analysis. American Journal of Trade and Policy, 5(3), 130-138.

\section{SOCIAL SCIENCE RESEARCH NETWORK \\ 2171 Monroe Avenue, Suite 203, Rochester, NY 14618, USA http://www.ssrn.com/en/}

SSRN Link: http://www.ssrn.com/link/American-Journal-Trade-Policy.html 